\title{
Environmental Characteristics and Water Quality of a Drainage Basin Impacted by Human Activities
}

\author{
Josiani C. Oliveira \\ Dept. of Environmental and Sanitary Engineering, Santa Catarina State University \\ Av. Luiz de Camões, 2090, Conta Dinheiro, CEP: 88520-000, Lages - SC, Brazil \\ Tel: 55-49-3289-9284Ｅ-mail: josiani.oliv@gmail.com
}

\begin{abstract}
Vitor R. Becegato
Dept. of Environmental and Sanitary Engineering, Santa Catarina State University Av. Luiz de Camões, 2090, Conta Dinheiro, CEP: 88520-000, Lages - SC, Brazil
\end{abstract} Tel: 55-49-3289-9284Ｅ-mail: vitorvrb92@gmail.com

\section{Indianara F. Barcarolli}

Dept. of Environmental and Sanitary Engineering, Santa Catarina State University Av. Luiz de Camões, 2090, Conta Dinheiro, CEP: 88520-000, Lages - SC, Brazil Tel: 55-49-3289-9284Ｅ-mail: indianara.barcaroli@udesc.br

\author{
Alexandre T. Paulino (Corresponding author) \\ Graduate Program in Environmental Sciences, Santa Catarina State University \\ Av. Luiz de Camões, 2090, Conta Dinheiro, CEP: 88520-000, Lages - SC, Brazil
}

Dept. of Food and Chemical Engineering, Santa Catarina State University

BR 282, Km 374, CEP: 89870-000, Pinhalzinho - SC, Brazil

Tel: 55-49-2049-9589Ｅ-mail: alexandre.paulino@udesc.br

Valter A. Becegato

Dept. of Environmental and Sanitary Engineering, Santa Catarina State University 
Av. Luiz de Camões, 2090, Conta Dinheiro, CEP: 88520-000, Lages - SC, Brazil

Tel: 55-49-3289-9284Ｅ-mail: valter.becegato@udesc.br

Received: August 11, $2017 \quad$ Accepted: August 25, 2017

doi:10.5296/emsd.v6i2.11672ＵRL: https://doi.org/10.5296/emsd.v6i2.11672

\begin{abstract}
The aim of the present study was to determine the environmental characteristics and water quality of a drainage basin impacted by human activities in order to obtain quantitative information for helping the development of environmental management politics of soils, lakes, rivers and water resources. Physicochemical properties and concentrations of metals were determined in different water samples. Dissolved oxygen, $\mathrm{pH}$, turbidity, color, ammonia, phosphorus, phenol, copper, silver, lead, cadmium and iron differed from levels considered acceptable by international regulations, indicating potential environmental pollution due to land occupation and the improper disposal of domestic, industrial and agricultural waste. The leaching of pollutants from the soil to bodies of water was also found. Total dissolved solids, salinity, suspended solids, nitrate, nitrite and zinc levels were lower than the limits imposed by international regulations, but have been increasing over time. Urbanization, industrialization and agricultural processes in drainage basins significantly affect the natural characteristics of the environment, leading to an increase in the concentrations of pollutants and a reduction in the quality of water, plants and soils. As pollutants in drainage basins generally enter into soils, rivers, lakes and ocean, it is necessary to obtain quantitative information about the human impacts in the water quality for developing environmental management politics aiming to preserve the water resources.
\end{abstract}

Keywords: Environment, Drainage basin, Water resources, Metal, Management

\title{
1. Introduction
}

The water crisis of the $21^{\text {st }}$ century is the result of the improper management of resources (Rogers et al., 2006; Wang et al., 2016) and is associated with both water bioavailability and high demand. Other problem is the lack of effective environmental management politics for the preservation of drainage basins (Somlyody \& Varis, 2006). The improper disposal of domestic waste in water and soil has significantly contributed to the increase in the environmental pollution of drainage basins in urban areas due to the presence of inorganic and organic compounds and the bioaccumulation of these compounds in the natural environment (Mauad et al., 2015). Urban anthropogenic activities alter the water quality of drainage basins due to the influence on the biogeochemical mechanisms of the natural system (Machado et al., 2009; Al-Naimi et al., 2015).

The monitoring of the physicochemical properties of water in drainage basins can be used to determine anthropogenic sources of pollution and concentrations of metals (Brazil, 2005; 


\section{Macrothink}

Read et al., 2015). The essential parameters for establishing water quality are $\mathrm{pH}$, dissolved oxygen and organic matter (Netto et al., 2013). Different temperatures and intensities of solar radiation also exert an influence on natural physicochemical properties (Netto et al., 2013). While $\mathrm{pH}$ is an indicator of water quality, the type of soil indicates the degree of acidity or alkalinity (Netto et al., 2013). Levels of dissolved oxygen vary depending on seasonal conditions, temperature, photosynthetic activity, water turbulence and flow rate (Pouyat et al., 2006). Oxygen levels decrease in the presence of suspended solids and biodegradable organic matter contained in domestic and industrial waste (Chai et al., 2015). The decomposition of organic matter in bodies of water can lead to a significant reduction in dissolved oxygen and $\mathrm{pH}$ due to the formation of carbonic acid (Chai et al., 2015).

Determining the physicochemical properties and concentrations of metals in a drainage basin is important to monitoring and preserving the natural environment. Drainage basins in urban areas are significantly affected by anthropogenic actions, such as disorderly land occupation, a lack of basic sanitation measures, the improper disposal of pollutants, inefficient drainage systems, deforestation and the impermeabilization of soil due to paving and construction activities (Bhardwaj et al., 2010). Thus, the aim of the present study was to determine the environmental characteristics and water quality of a drainage basin impacted by human activities and assist in the definition of environmental policies directed at the management and monitoring of water during the land occupation processes. Physicochemical properties were determined, such as temperature, dissolved oxygen, conductivity, $\mathrm{pH}$, total dissolved solids, salinity, turbidity, apparent color, phenol, suspended solids, nitrate, nitrite, ammonia, phosphorus and chemical oxygen demand. Levels of copper, silver, lead, cadmium, iron and zinc were also determined in different water samples.

\section{Materials and Methods}

\subsection{Drainage Basin}

The drainage basin studied is located in an urban area of the city of Lages in the state of Santa Catarina in southern Brazil. The geographic coordinates are $27^{\circ} 47^{\prime} \mathrm{S}, 50^{\circ} 17^{\prime} \mathrm{WGr}$ (mean altitude: $938 \mathrm{~m}$; total area: 2722 hectares). The drainage basin has a mesothermal climate with a mean temperature of $22{ }^{\circ} \mathrm{C}$ and well-distributed rainfall. The region has slightly wavy ground and a maximum altitude of $1067 \mathrm{~m}$. The predominant vegetation is mixed rainforest.

\subsection{Water Sampling}

Water samples were collected from 57 different points (springs, confluences and intermediate points). Each point was identified using the ArcGis ${ }^{\circledR} 10.1$ software program in a georeferenced environment overlapping orthophotocharts (Figure 1). Twenty-three springs, twenty-six points of confluence and eight intermediate points were sampled. 


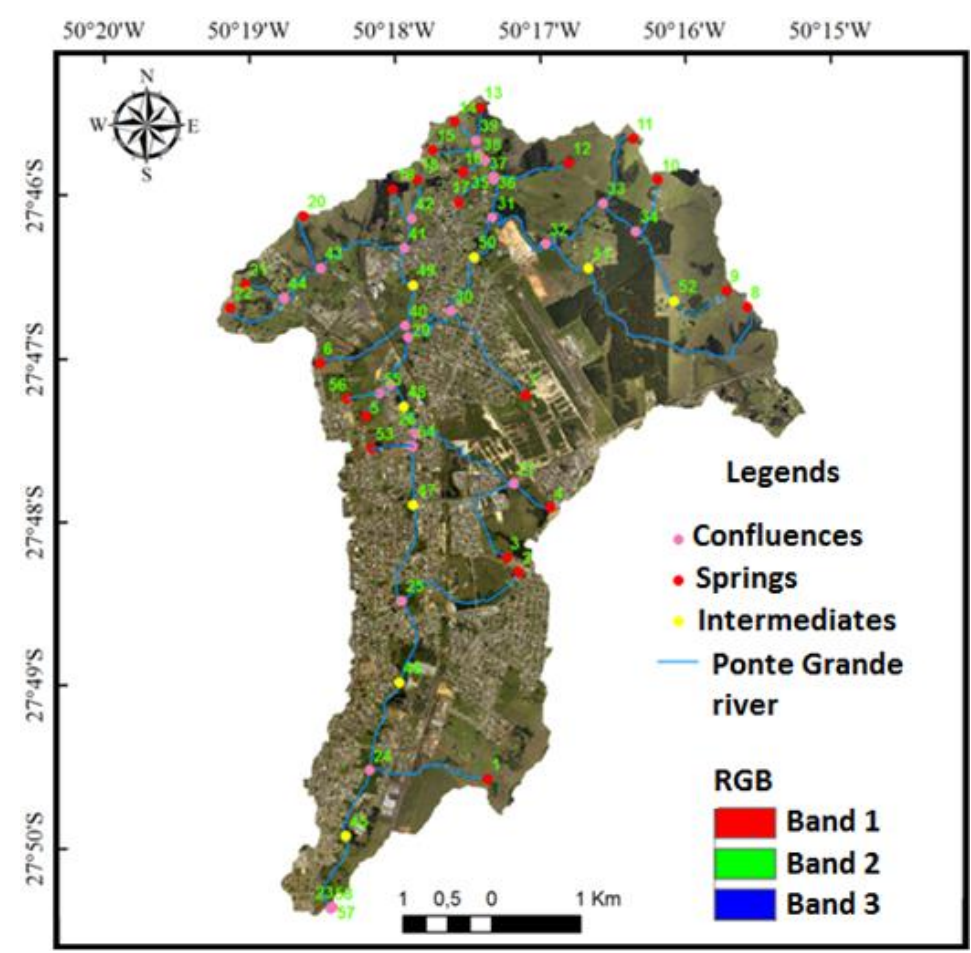

Figure 1. Water sample points in the drainage basin

Data on the hydrographic system, orthophotos and digital ground models on a scale of 1:10000 were studied. Samples were collected on sunny days with a mean temperature of $20{ }^{\circ} \mathrm{C}$ and the absence of rain and wind. Each sample was collected using a specific water bottle and stored in a polyethylene flask under refrigeration to preserve the physical, chemical and biological properties. Physicochemical properties were determined immediately after sampling using an Ysi Professional Plus multiparameter probe. These properties were determined again in the laboratory for confirmation.

\subsection{Physicochemical Properties}

Temperature, dissolved oxygen, conductivity, $\mathrm{pH}$, total dissolved solids, salinity, turbidity, apparent color, phenol, suspended solids, nitrate, nitrite, ammonia, phosphorus and chemical oxygen demand were determined in the laboratory for each water sample using standard methods for the examination of water and wastewater (Apha, 1999). Color, turbidity, suspended solids and chemical oxygen demand were determined in raw samples using a Spectroquant Nova 60 Merck spectrophotometer. Ammonia, phosphorus, nitrate, nitrite and phenol were determined in samples filtered through a Millipore membrane system prior to analysis by UV-vis spectrophotometry.

\subsection{Metal Concentrations}

The samples were prepared for the determination of metals using standard methods for the examination of water and wastewater (Apha, 1999). Briefly, $100.0 \mathrm{~mL}$ of well-mixed, acid-preserved water samples were placed in 125.0-mL Erlenmeyer flasks and $5.0 \mathrm{~mL}$ of concentrated nitric acid were added to each flask. The flasks were placed on a hot plate and 


\section{Macrothink}

heated slowly to $120^{\circ} \mathrm{C}$. After reaching a sample volume of 10.0 to $20.0 \mathrm{~mL}$, the remaining solutions were cooled to room temperature and transferred to 100-mL flasks, which were then filled to the maximum volume with Milli- $\mathrm{Q}^{\circledR}$ water. The samples were stored in amber glass vials prior to the determination of copper, silver, lead, cadmium, iron and zinc by flame atomic absorption spectroscopy (Spectrometer AAS 932 Plus - GBC, IL, USA; air-acetylene flame, $0.0200 \mathrm{mg} \mathrm{L}^{-1}$ detection limit).

\subsection{Descriptive Statistics}

Descriptive statistic analysis was performed with the aid of the STATISTIC® 7.0.

\section{Results and Discussion}

\subsection{Physicochemical Properties}

Tables 1a-b show the physicochemical properties of the water samples collected from the drainage basin studied. Dissolved oxygen, ammonia, phosphorus, phenol, $\mathrm{pH}$, turbidity and color differed from levels considered acceptable by international regulations, indicating that the water is unsuitable for consumption. The water of the drainage basin studied goes through various soils, lakes and rivers until entering the Atlantic Ocean (Figure 2). Consequently, this contaminated water can increase the environmental pollution indices of different regions. In general, this study will be very important for proposing appropriate environmental management politics that avoid pollutions in Brazil. This study can also be an example for other countries that worry with anthropologic activities near drainage basins in urban and industrial areas. Moreover, the polluted water of a drainage basin brings up health problems to animals and humans.

Table 1a. Physicochemical properties of the water samples collected from the drainage basin studied. T: temperature, DO: dissolved oxygen, DTS: dissolved total solids, SS: suspended solids, COD: chemical oxygen demand

\begin{tabular}{|l|l|l|l|l|l|l|l|}
\hline & $\begin{array}{l}\mathrm{T} \\
\left({ }^{\circ} \mathrm{C}\right)\end{array}$ & $\begin{array}{l}\text { DO } \\
(\mathrm{mg} / \mathrm{L})\end{array}$ & $\begin{array}{l}\text { Conductivity } \\
(\mu \mathrm{S} / \mathrm{cm})\end{array}$ & $\mathrm{pH}$ & $\begin{array}{l}\text { DTS } \\
(\mathrm{mg} / \mathrm{L})\end{array}$ & $\begin{array}{l}\text { Salinity } \\
(\mathrm{mg} / \mathrm{L} \text { x 10-6) }\end{array}$ & $\begin{array}{l}\text { Turbidity } \\
(\mathrm{uT}-\mathrm{FAU})\end{array}$ \\
\hline Minimum & 17.3 & 0.70 & 98.90 & 5.19 & 72.80 & 0.05 & 1.000 \\
\hline Maximum & 25.1 & 6.99 & 392.6 & 8.05 & 274.3 & 0.20 & 289.0 \\
\hline Mean & 19.9 & 3.76 & 201.1 & 6.84 & 145.7 & 0.11 & 31.40 \\
\hline Median & 19.7 & 4.24 & 182.9 & 7.14 & 133.2 & 0.10 & 16.00 \\
\hline SD & 1.53 & 1.53 & 74.20 & 0.86 & 54.40 & 0.04 & 42.00 \\
\hline CV $(\%)$ & 7.65 & 40.6 & 36.90 & 12.5 & 37.30 & 38.8 & 133.7 \\
\hline Asymmetry & 0.87 & -0.45 & 0.470 & -0.90 & 0.520 & 0.47 & 4.380 \\
\hline Kurtosis & 1.00 & -0.72 & -0.910 & -0.49 & -0.770 & -0.80 & 25.20 \\
\hline
\end{tabular}




\section{Macrothink}

Environmental Management and Sustainable Development

ISSN 2164-7682 2017, Vol. 6, No. 2

Table 1b. Physicochemical properties of the water samples collected from the drainage basin studied

\begin{tabular}{|l|l|l|l|l|l|l|l|l|}
\hline & $\begin{array}{l}\text { Color } \\
(\mathrm{uC}-\mathrm{Hz})\end{array}$ & $\begin{array}{l}\text { SS } \\
(\mathrm{mg} / \mathrm{L})\end{array}$ & $\begin{array}{l}\text { Nitrate } \\
(\mathrm{mg} / \mathrm{L})\end{array}$ & $\begin{array}{l}\text { Nitrite } \\
(\mathrm{mg} / \mathrm{L})\end{array}$ & $\begin{array}{l}\text { Ammonia } \\
(\mathrm{mg} / \mathrm{L})\end{array}$ & $\begin{array}{l}\text { Phosphorus } \\
(\mathrm{mg} / \mathrm{L})\end{array}$ & $\begin{array}{l}\text { COD } \\
(\mathrm{mg} / \mathrm{L})\end{array}$ & $\begin{array}{l}\text { Phenol } \\
(\mathrm{mg} / \mathrm{L})\end{array}$ \\
\hline Minimum & 0.500 & 2.000 & 0.020 & 0.03 & 0.05 & 0.010 & 0.09 & 0.005 \\
\hline Maximum & 327.0 & 237.0 & 1.410 & 0.33 & 8.95 & 0.530 & 53.9 & 0.060 \\
\hline Mean & 62.30 & 44.40 & 0.230 & 0.08 & 1.92 & 0.120 & 14,2 & 0.020 \\
\hline Median & 45.50 & 24.00 & 0.140 & 0.06 & 0.71 & 0.040 & 9.97 & 0.021 \\
\hline SD & 64.30 & 50,80 & 0.270 & 0.05 & 2.14 & 0.150 & 12.6 & 0.011 \\
\hline CV $(\%)$ & 103.2 & 114.2 & 117.8 & 64.3 & 111.1 & 132.1 & 88.7 & 41.22 \\
\hline Asymmetry & 2.890 & 2.140 & 3.050 & 2.88 & 1.190 & 1.350 & 0.98 & -0.095 \\
\hline Kurtosis & 8.650 & 4.350 & 10.50 & 10.2 & 0.690 & 0.490 & 0.32 & -0.819 \\
\hline
\end{tabular}

SD: Standard deviation, CV: Coefficient of variation

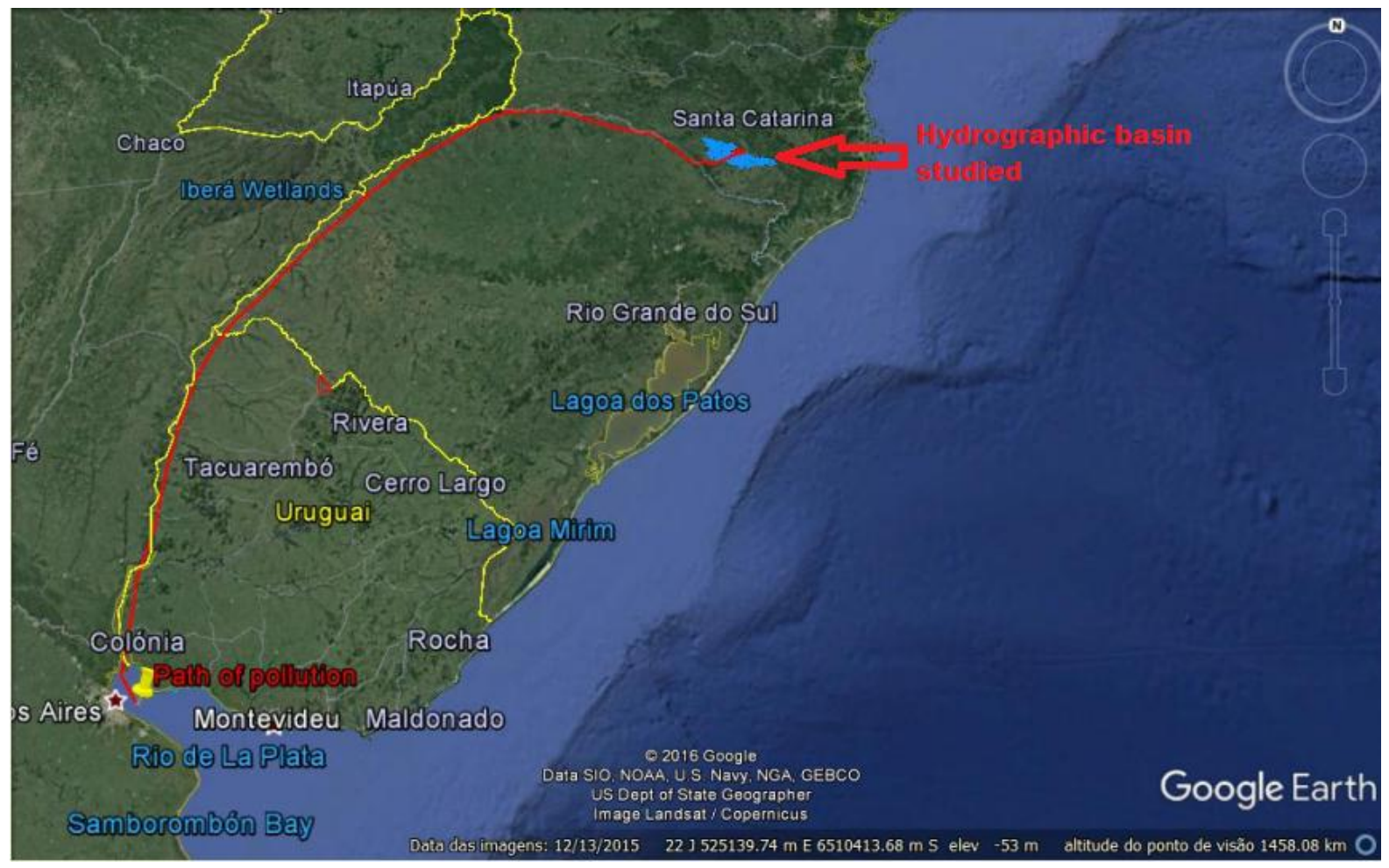

Figure 2. Water path of the drainage basin studied

Temperature exerts a significant influence on the metabolic activity of microorganisms, the velocity of chemical reactions and the solubility of substances (Tran et al., 2013), leading to differences in variables such as $\mathrm{pH}$, turbidity and color. Anthropogenic activities near drainage basins also affect the turbidity and color of water. Moreover, high ammonia, phosphorus and phenol concentrations are indicative of the influence of anthropogenic inputs and consequent environmental pollution. As the concentration of dissolved oxygen increased due to the influence of the variation in temperature, it is possible to conclude that the natural 
activities of microorganisms are not significant enough to contribute to the increase in environmental pollution. However, anthropogenic inputs play an important role in the environmental degradation of the drainage basin studied. Lower temperatures were found in the springs due to presence of vegetation and less sunlight.

Dissolved oxygen is essential for aerobic aquatic beings and its level in river water depends on temperature, salinity, water movement and atmospheric pressure. The concentration decreases at lower temperatures and during the decomposition of organic matter by microorganisms (Said et al., 2004). Dissolved oxygen concentrations in the drainage basin studied differed from those considered suitable by international regulations, which was associated with the presence of algae and organic matter from anthropogenic sources. Oxygen concentrations from 4.0 to $5.0 \mathrm{mg} \mathrm{L}^{-1}$ were determined in some water samples, which can cause the death of aerobic beings (Neto et al., 2013). Moreover, oxygen concentrations were lower than $4.0 \mathrm{mg} \mathrm{L}^{-1}$ in $70 \%$ of the drainage basin, indicating that the water is unsuitable for fishes or other aerobic living beings. Anthropogenic sources and irregular land occupation are predominant factors in the environmental pollution of drainage basins. The dissolved oxygen concentrations in the confluence and intermediate points located in urban areas (P5, P26, P27, P28, P29, P30, P40, P42, P48, P49, P50 and P54) were lower than $2.0 \mathrm{mg} \mathrm{L}^{-1}$, indicating significant environmental degradation. Most of these points are near areas of domestic and industrial waste discharge. The lowest oxygen concentration was determined at P50 (0.70 mg $\mathrm{L}^{-1}$ ), which is located in a region with a high population density.

Conductivity values at points $\mathrm{P} 8$ and $\mathrm{P} 12$ were lower than $100 \mu \mathrm{S} \mathrm{cm}{ }^{-1}$. Maximum conductivity ( $392.6 \mu \mathrm{S} \mathrm{cm}^{-1}$ ) was determined at P28. Different conductivity values in various points of a drainage basin are associated with the improper disposal of domestic, industrial or agricultural waste (Pereira et al., 2012). The coefficient of variation was $36.93 \%$ and minimum, maximum and average conductivities were 98.9, 392.6 and $201.11 \mu \mathrm{S} \mathrm{cm} \mathrm{cm}^{-1}$, respectively. Conductivity levels higher than $100 \mu \mathrm{S} \mathrm{cm}^{-1}$ indicate environmental degradation (Brazil, 2005; Libânio, 2010).

The turbidity values ranged from 1.000 to 289 NTU, with coefficient of variation of $133.7 \%$. Turbidity values higher than the acceptable limit for natural water were determined in confluences near urban areas due to the larger number of anthropogenic sources. This result is the consequence of the lack of environmental management regarding water and domestic sewage disposal. The improper disposal of domestic sewage in drainage basins increases the emerging pollutant concentration and environmental degradation. High turbidity values are associated with the decomposition of organic and inorganic matter by aerobic and anaerobic microorganisms (Pinheiro et al., 2014).

After the decomposition process, bioavailable organic matter decreases the $\mathrm{pH}$ of the water due to the production of organic acids and carbonic gas (Oliveira et al., 2009). pH values are important to the determination of water quality and the type of soil in a drainage basin. For instance, the $\mathrm{pH}$ of water considered of quality excellent ranges from 6.0 to 9.0 (Brazil, 2005). Values lower than 6.0 were determined at the confluence points indicated by P37, P38 and P39. Livestock and agricultural activities in these areas constitute two anthropogenic sources 
that may be altering water quality. Values lower than 6.0 were also determined at spring points P8, P9, P10, P11, P12, P13, P14, P15 and P16 due to the presence of domestic and agricultural waste near the water. The variation coefficient of $12.5 \%$ indicates that the $\mathrm{pH}$ in the natural environment of the drainage basin studied is the result of anthropogenic activities, which is in agreement with studies conducted in other drainage basins (Siqueira et al., 2012).

The watercolor in a drainage basin increases in the presence of iron, manganese, organic matter, algae and industrial/domestic waste (Netto et al., 2013). The watercolor in 11 springs, seven confluences and one intermediate point was higher than that considered acceptable by international regulations (Brazil, 2005). High coloration levels at points P5, P9, P14, P16 and P56 were associated with the excess organic matter from anthropogenic sources.

The ammonia concentrations in water samples collected from points P7 (spring), P26, P27, P29, P30, P33, P41, P54, P55 (confluences), P45, P46, P47, P48, P49 and P50 (intermediate points) were higher than those considered acceptable by international regulations. Higher ammonia concentrations were determined in water samples with a low level of dissolved oxygen. This result is the consequence of irregular land occupation in urban areas of the drainage basin studied. Domestic and industrial waste constitutes a constant source of anthropogenic pollution, whereas the flow of compounds of a natural origin on the soil surface is a seasonal phenomenon controlled by climate conditions (Bhardwaj et al., 2010). A high ammonia concentration in a natural environment indicates potential environmental pollution by nitrate and nitrite (Amneera et al., 2013).

Phosphorus concentrations ranged from 0.010 to $0.530 \mathrm{mg} \mathrm{L}^{-1}$, which are higher than the values considered acceptable by international regulations, indicating that eutrophication is taking place in the drainage basin studied (Kemerich et al., 2012). A high phosphorus concentration is also an indication of rock dissolution, the leaching of contaminated soil, organic matter decomposition and anthropogenic inputs from agricultural fertilizers as well as the improper discharge of livestock and domestic effluents (Machado et al., 2009). The phosphorus concentrations at points P7, P14 and P15 (springs) increased due to the growth of surrounding urban areas, indicating contamination due to human impacts on the environment. Riparian woodlands adsorb and remove phosphorus from water and low densities of such forests near springs determine an increase in phosphorus concentrations in water (Pinheiro et al., 2014). Lower phosphorus concentrations were determined at points P10, P11, P38, P39, P43 and P52 due to high density of riparian woodlands. The coefficient of variation for dissolved phosphorus levels was $132.1 \%$.

The mean chemical oxygen demand (COD) in the water samples collected from the drainage basin studied ranged from 0.09 to $53.9 \mathrm{mg} \mathrm{L}^{-1}$. COD values higher than $20.0 \mathrm{mg} \mathrm{L}^{-1}$ are characteristic of polluted water by either urban or industrial waste (Borges et al., 2003). Most points in the drainage basin studied had a COD higher than that considered acceptable by international regulations. For instance, the COD at points P41 (confluence) and P5 (spring) were 53.8 and $24.2 \mathrm{mg} \mathrm{L}^{-1}$, respectively. High COD levels are associated with the decomposition of organic matter by aerobic and anaerobic microorganisms.

Significant phenol levels were also determined in the water of the drainage basin studied. For 
instance, concentrations at points P9 and P41 were 0.0054 and $0.060 \mathrm{mg} \mathrm{L}^{-1}$, respectively, which are higher than values considered acceptable by international regulations, indicating contamination from anthropogenic sources, since phenol is not bioavailable in the environment. The pollution of drainage basins by phenol commonly results from the improper disposal of waste from paper, cellulose, mining, refinery, steel and coal-based energy production industries. Phenols are toxic to aquatic life even at low concentrations, altering water quality and the flavor of fish meat. Human intoxication by phenol can cause nausea, vomiting, oral pain and stomachache (Aker et al., 2016). The phenol concentration in water should be lower than $0.0030 \mathrm{mg} \mathrm{L}^{-1}$ (Brazil, 2005).

\subsection{Metal Concentrations}

Table 2 shows the statistical results of the concentrations of metals in the water samples collected from the drainage basin studied. Copper concentrations ranged from 0.046 (P7) to $1.347 \mathrm{mg} \mathrm{L}^{-1}$ (P39). Copper is naturally found in the environment. However, its bioavailable concentration is increased due to agricultural activities and fertilizer leaching processes in soils (Barros et al., 2009). High pH values and low water flow increase the adsorption of copper in plants and sediments (Bambic et al., 2006), increasing its bioaccumulation and toxic effect.

Table 2. Statistical results of the concentrations of metals in the water samples collected from the drainage basin studied

\begin{tabular}{|l|l|l|l|l|l|l|}
\hline & $\begin{array}{l}\text { Copper } \\
(\mathrm{mg} \mathrm{L-1})\end{array}$ & $\begin{array}{l}\text { Silver } \\
(\mathrm{mg} \text { L-1 })\end{array}$ & $\begin{array}{l}\text { Lead } \\
(\mathrm{mg} \text { L-1 })\end{array}$ & $\begin{array}{l}\text { Cadmium } \\
(\mathrm{mg} \text { L-1 })\end{array}$ & $\begin{array}{l}\text { Iron } \\
(\mathrm{mg} \text { L-1 })\end{array}$ & $\begin{array}{l}\text { Zinc } \\
(\mathrm{mg} \text { L-1 })\end{array}$ \\
\hline Minimum & 0.046 & 0.008 & 0.051 & 0.003 & 0.392 & 0.001 \\
\hline Maximum & 1.347 & 0.242 & 0.368 & 0.188 & 4.738 & 0.089 \\
\hline Mean & 0.370 & 0.150 & 0.180 & 0.080 & 1.560 & 0.040 \\
\hline Median & 0.310 & 0.180 & 0.180 & 0.080 & 1.400 & 0.040 \\
\hline SD & 0.241 & 0.080 & 0.070 & 0.050 & 0.900 & 0.020 \\
\hline CV $(\%)$ & 66.01 & 52.05 & 38.21 & 57.08 & 57.74 & 56.93 \\
\hline Asymmetry & 1.740 & -0.570 & 0.220 & 0.180 & 1.370 & 0.260 \\
\hline Kurtosis & 4.160 & -1.200 & 0.170 & -0.590 & 2.490 & -0.370 \\
\hline
\end{tabular}

SD: Standard deviation, CV: Coefficient of variation

Studies on the adsorption of copper to organic matter in drainage basins have demonstrated that the $\mathrm{pH}$ value and amount of particulate organic matter alter the distribution of copper in the water column (Scheffer et al., 2007). The mean copper concentration in the water of the drainage basin studied was higher than the median value, indicating asymmetrical distribution. Copper concentrations in 56 water samples were higher than that considered acceptable by international regulations (Figure 3). This indicates that the water is improper for consumption without prior treatment. The variability in the copper concentrations (coefficient of variation: $66.01 \%$ ) is the result of human impacts on the environment. The findings demonstrate leptokurtic distribution with concentrations around the mean value, as described for other drainage basins (Júnior, 2004). 


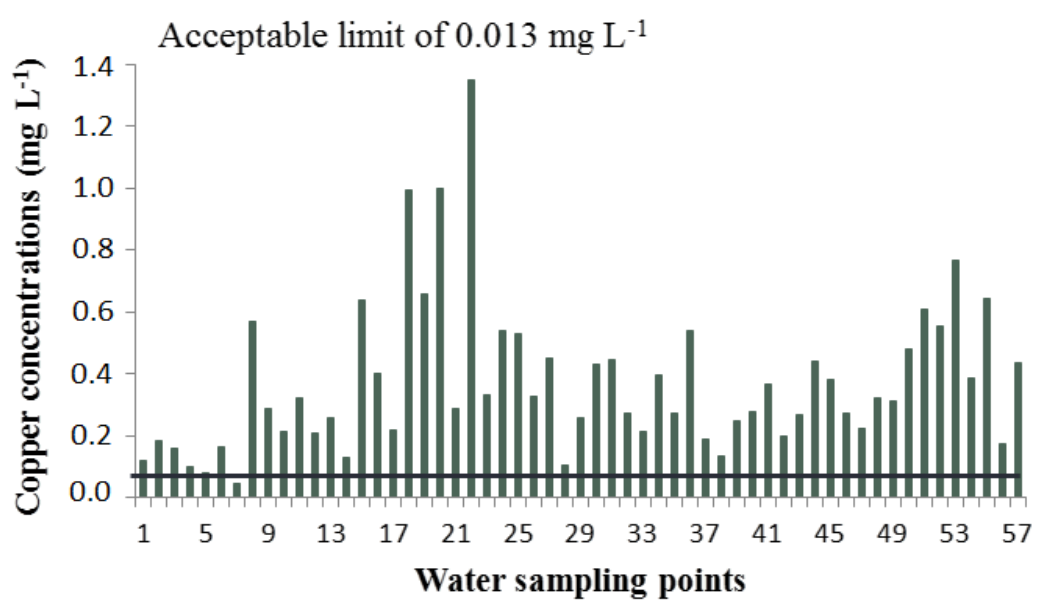

Figure 3. Copper concentrations in 57 water samples collected from the drainage basin

Silver concentrations ranged from $0.008(\mathrm{P} 5)$ to $0.242(\mathrm{P} 44) \mathrm{mg} \mathrm{L}^{-1}$. Silver occurs naturally at low concentrations in the environment. However, its concentration increases significantly due to industrial activities involving the production of photographic film and electronic devices. This metal is potentially toxic at high concentrations (Bendassolli et al., 2003). The silver concentration of $0.008 \mathrm{mg} \mathrm{L}^{-1}$ at P5 (spring) was lower than the limit imposed by international regulations. However, most of water samples had concentrations higher than the acceptable level due to the anthropogenic inputs in the drainage basin studied. Table 2 and Figure 4 show the mean silver concentrations at each point, with negative asymmetry in relation to the median. Significant variability in the data and platykurtic distribution were also found as described elsewhere (Júnior, 2004).

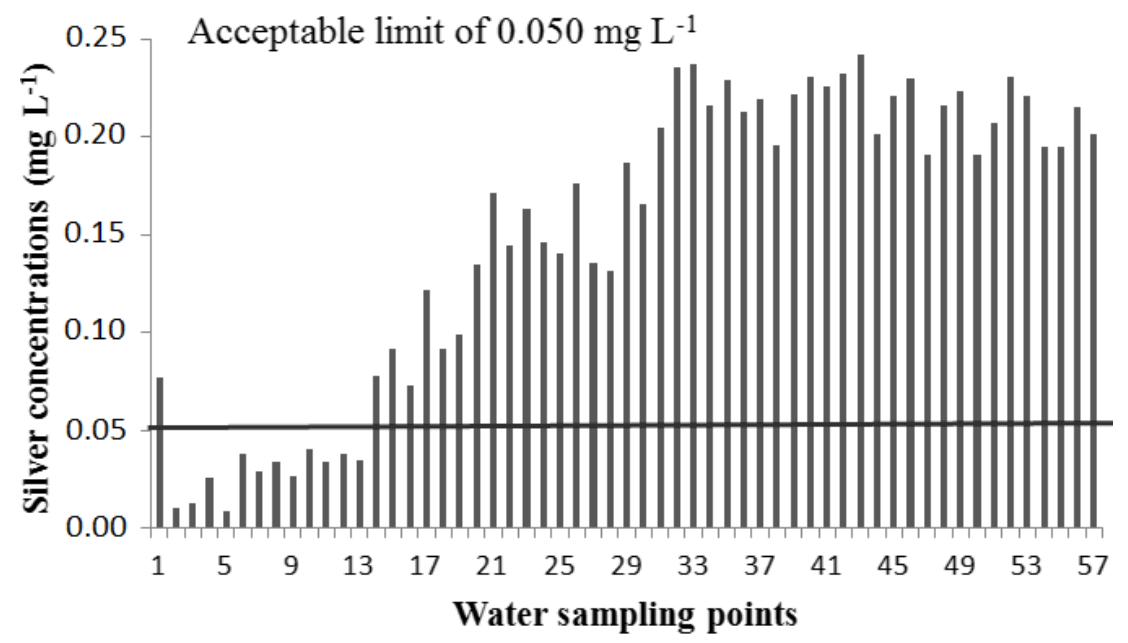

Figure 4. Silver concentrations in 57 water samples collected from the drainage basin

Lead concentrations ranged from $0.051(\mathrm{P} 43)$ to $0.368 \mathrm{mg} \mathrm{L}^{-1}(\mathrm{P} 30)$. The human activities responsible for lead contamination include the petroleum, paint, dye, ceramic, arms and vehicle battery industries (Paulino et al., 2008). Lead can enter the environment naturally through volcanic emissions and weathering (Mather, 2015). This metal is a neurotoxin that accumulates in muscular tissue, bone and viscera, damaging the central nervous system and causing brain disorders in animals (Paulino et al., 2005). Lead concentrations higher than that 
considered acceptable by international regulations were found in all water samples studied. High lead levels are associated with incineration processes and the improper disposal of metallurgy waste in the drainage basin studied. Moreover, lead can enter the environment through of the disposal of urban waste containing electronic devices. Table 2 and Figure 5 show a symmetric mean lead distribution around the median value. As the coefficient of variation was lower than $40 \%$, certain homogeneity in the experimental data and leptokurtic distribution were confirmed as described elsewhere (Alves et al., 2008).

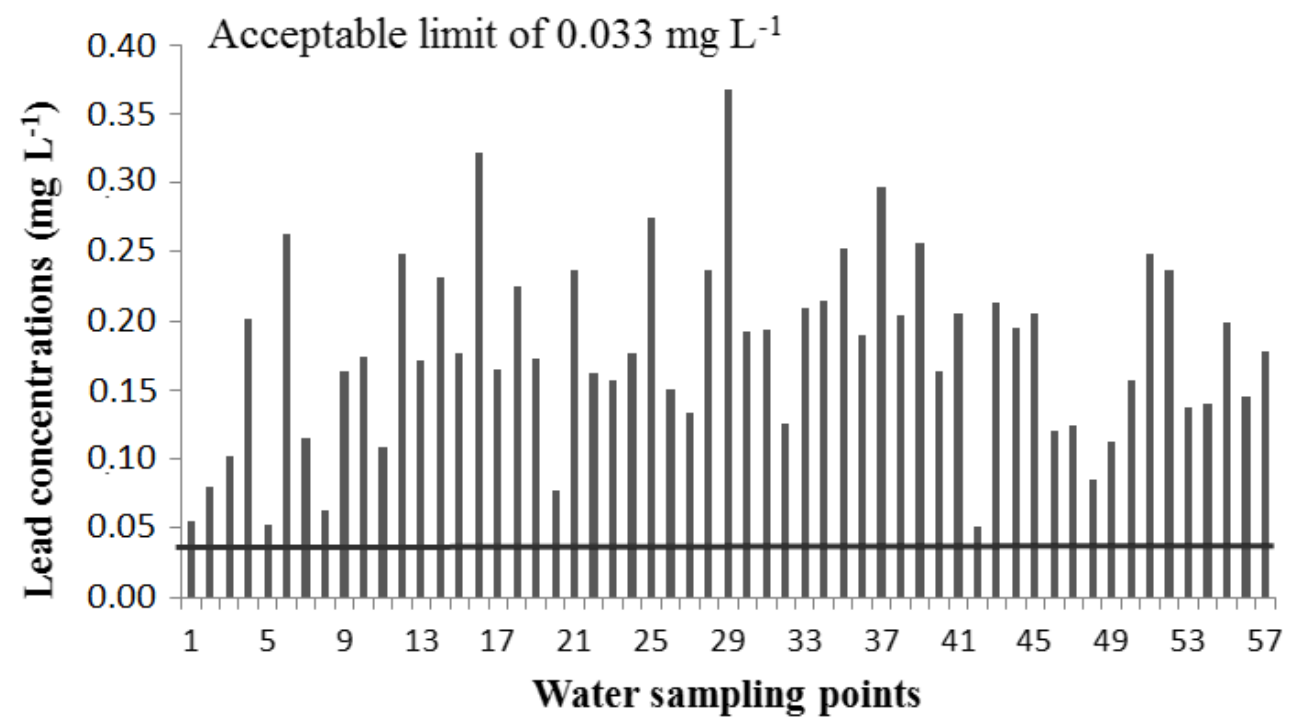

Figure 5. Lead concentrations in 57 water samples collected from the drainage basin

Cadmium concentrations ranged from 0.003 to $0.188 \mathrm{mg} \mathrm{L}^{-1}$. The values at P11 and P19 (springs) and P45 (intermediate point) were lower than the limit imposed by international regulations. However, concentrations for most water samples were higher than those considered acceptable (Figure 6). The highest cadmium concentration was determined at P16 (spring). High cadmium concentrations in drainage basins are associated with the leaching of sedimentary rock, volcanic activities and human impacts on the environment (Usepa, 2001). The main anthropogenic sources of cadmium pollution are associated with the mining, metallurgy and petroleum extraction industries. Moreover, domestic waste can have cadmium due the improper disposal of electronic devices and batteries. Considering the absence of metallurgic and petroleum extraction activities in the region of the drainage basin studied, it can be suggested that the cadmium contamination of the environment is directly associated with the improper disposal of domestic waste containing emerging pollutants. The distribution coefficient and kurtosis values indicate $57 \%$ variability in the experimental data and platykurtic distribution of cadmium (Table 2 and Figure 6). 


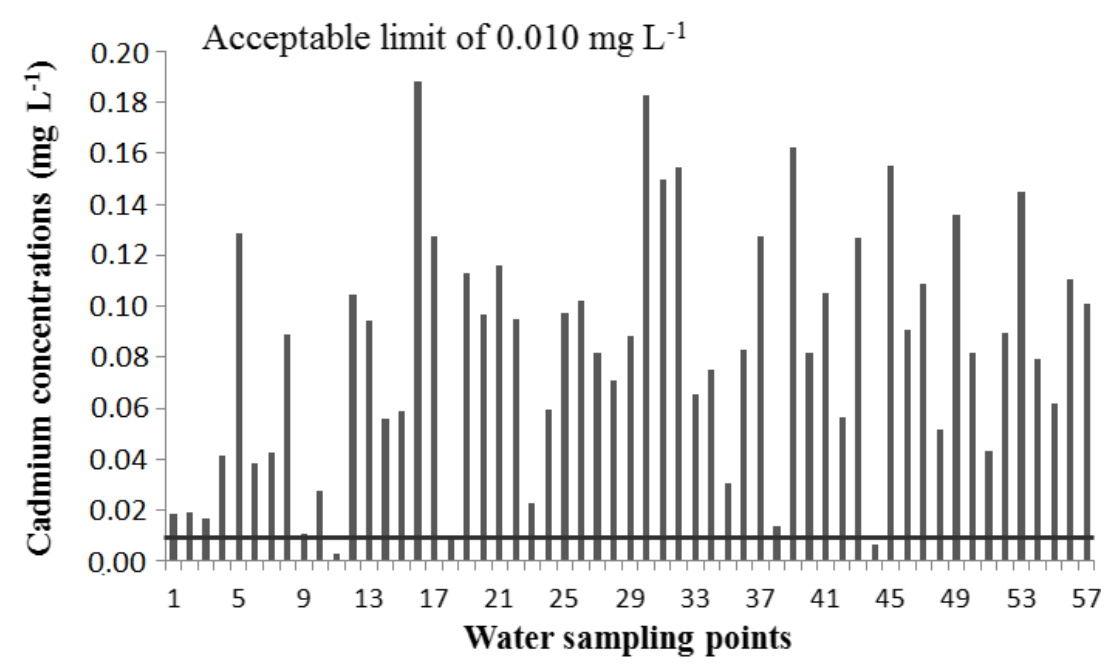

Figure 6. Cadmium concentrations in 57 water samples collected from the drainage basin

Total iron concentrations were 0.392 and $4.738 \mathrm{mg} \mathrm{L}^{-1}$ at P13 (spring) and P28 (confluence), respectively. All values were higher than those considered acceptable by international regulations due to human impacts on the environment. These concentrations are also associated with the biogeochemical composition of rocks and sediments in the region of the basin hydrographic. Iron and manganese are found in natural water due to soil and rock leaching processes (Azevedo \& Chasin 2003) as well as the improper disposal of domestic and industrial waste (Ilo, 1997). The most common anthropogenic sources of iron are mining, foundry, petroleum and domestic waste (Ilo, 1997). The total iron concentration in natural soil depends on the physicochemical properties of rock and degrees of weathering (Mather, 2015). The presence of iron and manganese yields water with a yellow coloration and high turbidity due to the precipitation of metal oxides and hydroxides (Richter \& Netto 1991). The values of the total iron concentrations shown in Table 2 and Figure 7 indicate positive asymmetry, $57 \%$ variability in the experimental data, heterogeneity of the values and leptokurtic distribution.

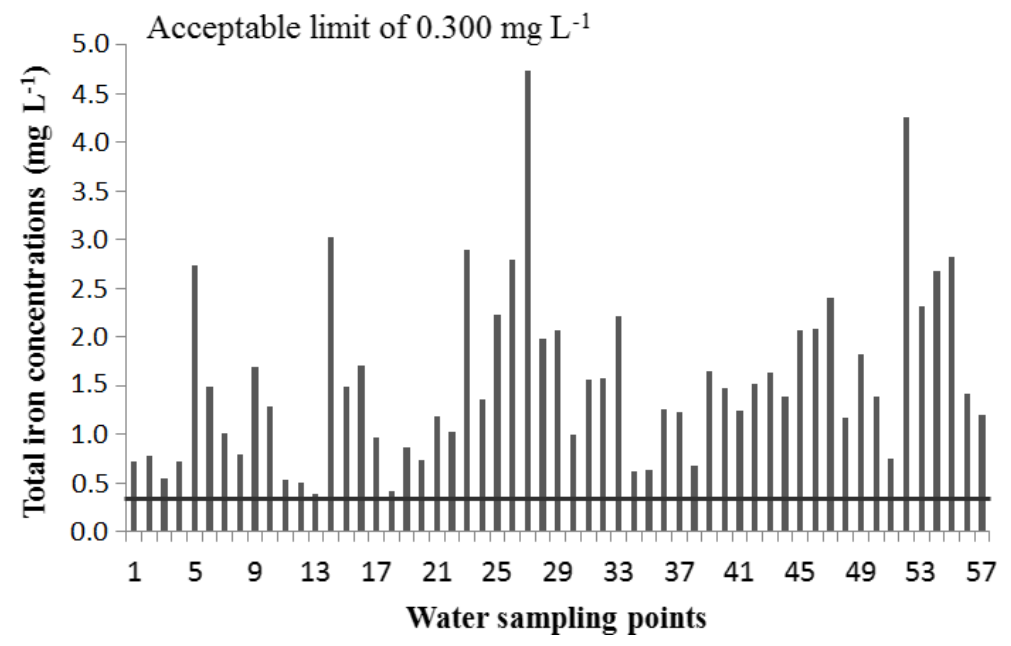

Figure 7. Total iron concentrations in 57 water samples collected from the drainage basin 
Zinc concentrations ranged from 0.001 to $0.089 \mathrm{mg} \mathrm{L}^{-1}$ in the drainage basin studied. All zinc concentrations were lower than the limit imposed by international regulations. In view of this, it was not shown a graphic with the total zinc concentrations in different sampling points. Zinc is an essential mineral for living beings that participates in important biological functions (Santos et al., 2011). Zinc deficiency can cause growth retardation, delayed sexual maturation, infection and diarrhea (Hambidge \& Krebs 2007). In contrast, the excessive daily ingestion of zinc can cause ataxia, lethargy and copper deficiency (Paulino et al., 2007). Zinc naturally occurs in the crust of the earth at an average concentration of $75.0 \mathrm{mg} \mathrm{L}^{-1}$, with 5.0 to $770.0 \mathrm{mg} \mathrm{L}^{-1}$ found in soils (Emsley, 2001). Symmetrical variability in the experimental data and platykurtic distribution were found for naturally occurring zinc in the drainage basin and no anthropogenic sources of this metal were identified during the experimental studies.

\section{Conclusion}

The environmental pollution of drainage basins due to the improper disposal of domestic and industrial waste modifies physicochemical properties and concentrations of metals in bodies of water. Moreover, environmental degradation has significantly increased due to leaching processes and the absence of riparian forests. The mean $\mathrm{pH}$, dissolved oxygen, turbidity, color, ammonia, phosphorus and phenol values in the water of the drainage basin studied were higher than those considered acceptable by international regulations. Mean total dissolved solids, salinity, suspended solids, nitrate, nitrite and zinc values were lower than the limits imposed by international regulations, but have been gradually increasing over time. The most polluted drainage basins are located near areas with a high population density and the degradation of such systems is the result of the improper disposal of domestic waste containing emerging pollutants. High concentrations of metals, such as copper, silver, lead, cadmium and iron, were also determined, indicating an increase in environmental pollution due to presence of electronic devices in domestic waste. It is necessary to monitor and characterize the water of drainage basins near urban areas for the definition of environmental management strategies. The environmental monitoring and management of drainage basins are important to the establishment of public politics aimed at avoiding the improper disposal of solid and liquid wastes in soil and water and preserving natural water sources. This can avoid the pollution of soils, lakes, river and ocean in some situations.

\section{Acknowledgments}

The authors gratefully acknowledge the Brazilian fostering agencies CAPES and FAPESC for research support. ATP acknowledges CNPq (Grants $\mathrm{N}^{\circ}$ 479402/2013-2 and 312356/2015-3) for financial support.

\section{References}

Aker, A. M., Watkins, D. J., Johns, L. E., Ferguson, K. K., Soldin, O. F., .. Meeker, J. D. (2016). Phenols and parabens in relation to reproductive and thyroid hormones in pregnant women. Environmental Research, 151, 30-37. https://doi.org//10.1016/j.envres.2016.07.002

Al-Naimi, H. A., Al-Ghouti, M. A., Al-Shaikh, I., Al-Yafe, M., \& Al-Meer, S. (2015). Metal distribution in marine sediment along the Doha Bay, Qatar. Environmental Monitoring 
Assessment, 187, 129-142. https://doi.org//10.1007/s10661-015-4352-6

Alves, M. C., Botelho, S. A., Pinto, L. V. A., Pozza, E. A., Oliveira, M. S., Ferreira, E., \& Andrade, H. (2008). Spatial variability of geobiophysical variables in the springs of the Ribeirão Santa Cruz watershed. Revista Brasileira de Engenharia Agrícola e Ambiental, 12, 527-535. https://doi.org//10.1590/S1415-43662008000500014

Amneera, W. A., Najib, N. W. A. Z., Mohd, S. R., \& Ragunathan, Y. S. (2013). Water quality index of Perlis River, Malaysia. International Journal of Civil and Environmental Engineering, $13,1-6$.

Apha, (1999). Standard methods for the examination of water and wastewater, Washington, Apha.

Azevedo, F. A., \& Chasin, A. A. M. (2003). Metais: gerenciamento da toxidade, São Paulo, Atheneu.

Bambic, D. G., Alpers, C. N., Green, P. G., Fanelli, E., \& Silk, W. K. (2006). Seasonal and spatial patterns of metals at a restored copper mine site. I. Stream copper and zinc. Environmental Pollution, 144, 774-782. https://doi.org//10.1016/j.envpol.2006.02.019

Barros, F. M., Martinez, M. A., Matos, A. T., Cecon, P. R., Moreira, D. A., \& Rosa, D. R. Q. (2009). Chemical elements potentially toxic at different flow rates in the Turvo Sujo river, MG, Brazil. Revista Ambiente \& Água, 4, 93-105. https://doi.org//10.4136/ambi-agua.89

Bendassolli, J. A., Tavares, G. A., Ignoto, R. F., \& Rosseti, A. L. R. M. (2003). Recovering procedures for liquid and solid Ag residues. Química Nova, 26,

578-581. https://doi.org//10.1590/S0100-40422003000400023

Bhardwaj, V., Singh, D. S., \& Singh, A. K. (2010). Water quality of the Chhoti Gandak river using principal component analysis, Gnga Plain, India. Journal of Earth System Science, 119, 117-127. https://doi.org/10.1007/s12040-010-0007-8

Borges, M. J., Galbiatti, J. A., \& Ferraudo, A. S. (2003). Monitoramento da qualidade hídrica e eficiência de interceptores de esgoto em cursos d'água urbanos da bacia hidrográfica do córrego Jaboticabal. Brazilian Journal of Water Resources, 8, 161-171.

https://doi.org//10.21168/rbrh.v8n2.p161-171

Brazil, (2005). Resolution number 357/2005. http://www.mma.gov.br/port/conama, Accessed 22 December 2016.

Chai, C. C., Lee, Z. H., Toh, P. Y., Chieh, D. C. J., Ahmad, A. L., \& Lim, J. K. (2015). Effects of dissolved organic matter and suspended solids on the magnetophoretic separation of microalgal cells from an aqueous environment. Chemical Engineering Journal, 281, 523-530. https://doi.org/10.1016/j.cej.2015.06.108

Emsley, J. (2001). "Zinc". Nature's building blocks: An A-Z guide to the elements, England, Oxford University Press.

Hambidge, K. M., \& Krebs, N. F. (2007). Zinc deficiency: a special challenge. Journal of 
Nutrition, 137, 1101-1105.

Ilo, (1997). Encyclopedia of occupational health and safety. Metals: chemical properties and toxicity, Geneva, Ilo.

Júnior, J. I. R. (2004). Análises estatísticas no Excel: guia prático, Viçosa, Universidade Federal de Viçosa.

Kemerich, P. D. C., Silva, R. F., \& Reque, P. T. (2012). Determination of the index of water quality in Esperança Stream. Ciência e Natura, 34, 83-98.

Libânio, M. (2010). Fundamentos de qualidade e tratamento de água, Campinas, Átomo.

Machado, W. C. P., Becegato, V.A., Bittencourt, A.V.L., \& Cabral, J.B.P. (2009). Water quality of Conrado river located in Pato Branco river basin - southwestern of the Paraná State. Revista Ra'e ga: Espaço Geográfico em Análise, 17, 53-64.

Mather, T. A. (2015). Volcanoes and the environment: Lessons for understanding Earth's past and future from studies of present-day volcanic emissions. Journal of Volcanology and Geothermal Research, 304, 160-179. https://doi.org/10.1016/j.jvolgeores.2015.08.016

Mauad, C. R., Wagener, A. L. R., Massone, C. G., Aniceto, M. S., Lazzari, L., Carreira, R. S., \& Farias, C.O. (2015). Urban rivers as conveyors of hydrocarbons to sediments of estuarine areas: Source characterization, flow rates and mass accumulation. Science of the Total Environment, 506-507, 656-666. https://doi.org/10.1016/j.scitotenv.2014.11.033

Neto, S. L. R., Becegato, V. A., \& Cabral, J. B. P. (2013). Caveiras river water quality monitoring in planalto serrano (Santa Catarina state) through geomatic support technologies. Boletin Goiano de Geografia, 33, 27-46.

Netto, A. O. A., Garcia, C. A. B., Alves, J. P. H., Ferreira, R. A., \& Silva, M. G. (2013). Physical and chemical characteristics of water from the hydrographic basin of the Poxim River, Sergipe State, Brazil. Environmental Monitoring Assessment, 185, 4417-4426. https://doi.org/10.1016/10.1007/s10661-012-2880-x

Oliveira, T. M. B. F., Di Souza, L., \& Castro, S. S. L. (2009). Behavior of nitrogen series in the waters of the Apodi/Mossoró basin - RN - Brazil. Eclética Química, 34, 17-26. https://doi.org//10.1590/S0100-46702009000300002

Paulino, A. T., Santos, L. B., \& Nozaki, J. (2007). Protective action of zinc against lead poisoning in tilapia Oreochromis niloticus. Toxicological \& Environmental Chemistry, 89, 363-370. https://doi.org//10.1080/02772240601056686

Paulino, A. T., Santos, L. B., \& Nozaki, J. (2008). Removal of $\mathrm{Pb}^{2+}, \mathrm{Cu}^{2+}$, and $\mathrm{Fe}^{3+}$ from battery manufacture wastewater by chitosan produced from silkworm chrysalides as a low-cost adsorbent. Reactive \& Functional Polymers, 68, 634-642.

https://doi.org/10.1016/j.reactfunctpolym.2007.10.028

Paulino, A. T., Tessari, J. A., Nogami, E. M., Lenzi, E., \& Nozaki, J. (2005). Lipid increase induced by lead accumulation in tilapia Oreochromis niloticus. Bulletin of Environmental 
Contamination and Toxicology, 75, 42-49. https://doi.org/10.1007/s00128-005-0716-x

Pereira, P. S., Fernandes, L. A. C., Oliveira, J. L. M., \& Baptista, D. F. (2012). Assessment of water quality in areas of ecological economic zoning of the Guapiaçu-Macacu basin, RJ, Brazil. Revista Ambiente \& Água, 7, 157-168. https://doi.org//10.4136/ambi-agua.762

Pinheiro, A., Schoen, C., Schultz, J., Heinz, K. G. H., Pinheiro, I. G., \& Deschamps, F. C. (2014). Relação entre o uso do solo e a qualidade da água em bacia hidrográfica rural no bioma mata atlântica. Brazilian Journal of Water Resources, 19, 127-139.

https://doi.org//10.21168/rbrh.v19n3.p127-139

Pouyat, R. V., Yesilonis, I. D., Russell-Anelli, J., \& Neerchal, N. K. (2006). Soil chemical and physical properties that differentiate urban land-use and cover types. Soil Science Society of America Journal, 71, 1010-1019. https://doi.org//10.2136/sssaj2006.0164

Read, E. K., Patil, V. P., Oliver, S. K., Hetherington, A. L., Brentrup, J. A., .. Weathers, K.C. (2015). The importance of lake-specific characteristics for water quality across the continental United States. Ecological Applications, 25, 943-955. https://doi.org//10.1890/14-0935.1

Richter, C. A., \& Netto, J. M. A. (1991). Tratamento de água: tecnologia atualizada, São Paulo, Edgard Blucher.

Rogers, P. P., Llamas, M. R., \& Martínez-Cortina, L. (2006). Water crisis: myth or reality? London, Taylor \& Francis.

Said, A., Stevens, D. K., \& Sehlke, G. (2004). An innovative index for evaluating water quality in streams. Environmental Management, 34, 406-414.

https://doi.org//10.1007/s00267-004-0210-y

Santos, L. B., Paulino, A. T., Tambourgi, E. B., \& Almeida, V. C. (2011). Toxic effects of dietary of $\mathrm{Al}^{3+}$ ions in tilapias (Oreochromis niloticus) and protective effect of $\mathrm{Zn}^{2+}$ íon. Toxicological \& Environmental Chemistry, 93, 92-101.

https://doi.org//10.1080/02772248.2010.486232

Scheffer, E. W., Sodré, F. F., \& Grassi, M. T. (2007). Factors governing copper speciation in urban freshwaters: evidences on the contribution of soluble sulfides. Química Nova, 30, 332-338. https://doi.org//10.1590/S0100-40422007000200018

Siqueira, G. W., Aprile, F., \& Miguéis, A. M. (2012). Diagnostic of the water quality of the Parauapebas River (Pará, Brazil). Acta Amazônica, 42, 413-422.

https://doi.org//10.1590/S0044-59672012000300014

Somlyody, L., \& Varis, O. (2006). Freshwater under pressure. International Review for Environmental Strategies, 6, 181-204.

Tran, N. H., Urase, T., Ngo, H. H., Hu, J., \& Ong, S. L. (2013). Insight into metabolic and cometabolic activities of autotrophic and heterotrophic microorganisms in the biodegradation of emerging trace organic contaminants. Bioresource Technology, 146, 721-731.

https://doi.org//10.1016/j.biortech.2013.07.083 


\section{Macrothink \\ Environmental Management and Sustainable Development \\ ISSN 2164-7682 2017, Vol. 6, No. 2}

Usepa, (2001). Drinking water standards and health advisories.

http://water.epa.gov/drink/standards/hascience.cfm, Accessed 10 June 2016.

Wang, W., Tang, D., Pilgrim, M., \& Liu, J. (2016). Water resources compound systems: a macro approach to analysing water resource issues under changing situations. Water, 8, 1-12. https://doi.org//10.3390/w8010002

\section{Copyright Disclaimer}

Copyright for this article is retained by the author(s), with first publication rights granted to the journal.

This is an open-access article distributed under the terms and conditions of the Creative Commons Attribution license (http://creativecommons.org/licenses/by/3.0/). 